\title{
Fundamental Principles and Financial Managements of the Insured Education System Model (IESM)
}

\author{
Seniha Çelikhan \\ Gebze Teknik Üniversitesi, Kocaeli, Turkey
}

\begin{abstract}
In the educational field, there is a need for a system to become effective, useful, and easily affordable and should include users' participation. This need was the main reason; the model named "Insured Education System Model-IESM" is designed by author. The IESM is based on the principal whose expenditures of education in each expenditure entry level will not be paid by the person itself. The insurance foundations are established to cover the educational expenditures of the buyers. Suggested model could bring an auto-control to the mechanism; from the cycle IESM generates, the educational insurance foundations, educational institutions, buyers, and households get benefits. Furthermore, IESM can increase the quality of service, educational system, employment, and numbers of students. The result should decrease the cost of the service. This study draws on the perception that the participating, payable, profitable, and proponent IESM is likely to be accepted by the families who are already under the burden of education cost of their children, therefore, it is likely to be applicable in practice. A descriptive and qualitative research method is employed. A five-point Likert-scales based survey is prepared. Then, approval rates of the IESM among households, students, and teachers are measured. The results show that the model received a high approval level. In this paper, the fundamental principles and financial management models, joint education account, and education investment partnership (EIP), which are the education financing systems proposed in IESM, are discussed.
\end{abstract}

Keywords: insurance, education, principles, finance, management, profit

\section{Introduction}

Statistical figures on national education data have shown that the resources allocated to the national education are not adequate; the educational needs of the entire population can't be met by the state budget; the supply is insufficient to meet the demand; therefore, education opportunity is not offered on equal terms and not everybody can benefit from these opportunities equally. The private prep courses out of formal education system have caused an exponential increase in the cost of education which families have to pay. The figures also show that there is a huge difference in cost between private and public school spending. Students from underprivileged households are deprived of the opportunity to attain education up their desired level and demand for education differs along the line of socio economic levels in the society. Kindergartens are in low demand except for the compulsory education institutions, private schools can't flourish within the current education system, and student can't attain the education they desire.

Seniha Çelikhan, Ph.D., professor, City and Regional Planning, Gebze Teknik Üniversitesi, Kocaeli, Turkey.

Correspondence concerning this article should be addressed to Seniha Çelikhan, Gebze Teknik Üniversitesi, Mimarlık Fakültesi, Şehir ve Bölge Planlama Bölümü 41400 Gebze/Kocaeli, Turkey, P.K: 141. E-mail: celikhan@gyte.edu.tr. 
In the field of education in Turkey (Türkiye İstatistik Kurumu, 2007; Devlet Planlama Teşkilat1, 2007; Çelikhan, 2007), there is a need for a financing system, which is affordable, yet effective, as well as profitable, and is based on user participation. This model establishes the basis for an education financing system after consideration of the merchanting houses (Retrieved from http://www.irs.gov/newsroom/article/0,,id=107670,00. html; Retrieved from www.vakifbank.com.tr/1501.aspx; Retrieved from www.akemeklilik.com. tr/hayat_urunleri/surekli_egitim_sigortasi.asp; Retrieved from www.fortis.com.tr/bireysel/ideal_egitim_ sigortasi.jsp; Retrieved from www.tebsigorta.com.tr/BireyselSigortacilik/CocukEgitimiOzellikler.aspx; Retrieved from www.axaoyak.com.tr/u-ce.asp) is created by the author based on revenues created through JEIA and/or Education Investment Partnership (EIP), which would pay for current or future financial needs of education. In this way, a sustainable funding for education is made affordable through small payments. In case of death, disability, or retirement of the investor, the education costs are continued to be paid without interruption by means of education insurance, pension, or through bursaries and loans granted to students. In this way, young prodigies who might miss out on education due to lack of funding can be integrated into the society and the humanity. The model also entails more efficient human resource management and creates employment, all the while paving the way for development of innovation centers where natural resources are sustainably utilized.

Method in the study, which draws on the perception that the participating, payable, profitable, proponent insured education system, is likely to be accepted by the families who are already under the burden of education cost of their children, therefore it is likely to be applicable in practice. A descriptive and qualitative research method is employed. A five-point Likert-scales based survey is prepared. Then, approval rates of the IESM among households, students, and teachers are measured. The results show that the model received a high approval level. The surveys are conducted in preschool, elementary and secondary school levels in selected districts of Istanbul, namely Kadıköy, Beyoğlu, Fatih, Adalar, and Tuzla. The research units are households who have children attending in these schools, and the teachers. It is assumed that the selected districts have appropriate representation of the target groups. The questionnaire is pre-tested for reliability and validity by a group of 15 people at the Gebze Institute of Technology, and revised accordingly. The survey forms included a brief explanation of the Insured Education System Model (IESM) in the front page, and the 42 questions on the next page aiming at measuring the approval rate of the model, in addition to the descriptive information about respondents. The surveys are sent to the schools through their corresponding District Education Directorates under the permit of the Provincial Directorate of National Education. During this process, the questionnaire is controlled by the inspectors of the Provincial Directorate of National Education and a permit document is issued. Then, a total number of 4,000 surveys are delivered to the District Education Directorates along with the permit to be forwarded to the schools. Each school principal was in charge of conducting the survey, making sure that the questions were answered by a teacher and three households for each independent variable, namely, "number of children", "education level", "income level", and "occupation", totalling up to 13 units from each school. Then the principals are sent back with the surveys to the District Education Directorates. The total number of surveys which were sent back is 2,369 . The return rate of the survey is $60 \%$. Statistical analyses on the data from the surveys are done via SPSS program. The data is examined through frequency analyses, cross tabulation, descriptive distribution of the variables. Relationships among the variables are tested using Ki-Square test. A variance analysis is conducted on the answers by the variables. Later, the 42 questions are grouped under four components through factor analysis, and then the relationship among the four components 
and the variables are examined. In this article, the fundamental principles and financial management models, joint education account, and EIP, which are the education financing systems proposed in IESM, are discussed.

Joint education account and EIP financial management models reconstruct the approaches of all of the participants of IESM (government, educational institutions, financial institutions, and households) and all the transaction practices of the current financial management systems (stipend, banking transacton, cooperatives, joint-stock companies, sponsors, pension fund, and foundations) in line with the objectives of the IESM.

\section{Fundamental Principles of the Model of Participatory, Payable, Profitable, Potent, IESM}

- Public or private financing companies whose legal frameworks are defined by the law shall prepare financial schemes in the form of education investment packages, providing alternatives for the types of payment of the investment, or repayment options (annual, multi-year, total), as deemed appropriate for students enrolled in schools at different stages of education, and in consideration of education cost demanded by educational institutions;

- Households, or natural and legal persons who would like to be a sponsor of education, or the student him/herself shall sign contract with the public or private financing company of their choice for the chosen education investment package through a JEIA or EIP;

- The cost of education, for which a contract has been signed, shall be paid by the parents, the sponsor individuals, or institutions (by installments or as immediate payment); the student, who has received bursary or loan, shall pay back when he/she graduates based on the credit value of that year in terms of compulsory service or interest free money depending on the circumstances;

- The student shall enroll to a school of his/her choice among those which conform the conditions of the education investment package he/she has signed for, then shall submit documents of school enrollment to public or private financing company, which has offered the education investment package in question;

- The public or private financing company, which has offered the education investment package, shall pay for the education cost of the student in accordance with the conditions set out by the contract signed by the both parties;

- Educational institutions, which receive quality certificate, shall prepare price lists for payment packages of financing companies and shall sign contract with any financing company of their choice;

- The government shall prepare legal framework for the IESM model;

- There will be competition among financing companies; a parent, student, individual, or institution (investor) will choose to sign a payment contract through the most reliable JEIA or EIP which offers better payment scheme and various combinations of education package; whereas an educational institution will opt for signing a contract with the most reliable JEIA or EIP, which has the highest capital and ability to pay top prices;

- There will be competition among educational institutions. A parent or student will enroll to a school which offers higher quality of education, whereas a financing company will opt for signing a contract with an educational institution which has the highest capital capacity and offers the best quality of service at the lowest price;

- There will be interaction among actors of the IES model, such as parent/student, financing company, and educational institution; 
- Actors of the model will create self-control mechanism over one another;

- All of the actors who take part in the IES model will benefit from the system at the highest level;

- Through this model, a sustainable service system with high quality, affordable/expensive, participatory, and effective, is encouraged;

- The model system is open to improvement on requests of the actors (to increase quality, to lower/increase price, to increase number of students, to increase employment, to grow capital, and to enlarge service area);

- Education payment packages shall offer different alternatives and shall cover all education levels, (kindergarten, compulsory education, high school, university, graduate school, and Doctorate program), and all schools (public or private schools, universities, and higher technology institutions);

- Public schools shall be privatized within the IESM or shall be managed by the state within the framework of the IESM;

- Household and student will be both the controller and the beneficiary of the system;

- The quality gap among educational institutions will diminish;

- There will be no social class differences in education; students coming from low income or poor background will exercise their constitutional right of education on equal setting as those of higher income;

- Household and student who choose not to sign a payment contract through a JEIA or EIP will pay education cost to the school on their own;

- The IESM is encouraging in its core;

- The system is subject to the relevant open market rules;

- The system provides education opportunity at any level in any condition;

- This model promotes institutional cooperation amount financing companies, educational institutions and household/students.

\section{Financing Structure of Model of Participating, Payable, Profitable, Proponent IESM}

The model is structured to create an auto-control mechanism through a financing system based on cooperation among educational support institutions, educational finance Institutions, and beneficiaries, and to increase service and quality based on free market principles, while maximizing benefit and minimizing education cost. This system can briefly be described as a model based on certain basic principles, which functions through joint education accounts or education investment funds within finance institutions and flexible to adjust advantages provided to the beneficiaries. Education support institutions are expected to deposit money in these accounts and the money collected in these escrow accounts will be paid by the financing agency to the contracted educational institutions under education insurance framework to cover all the educational cost of the beneficiary, and the profit from these transactions of lump sum money is to be transferred into education expenses.

\section{JEIA}

JEIA will be based on individual education saving accounts with tax reduction and dividend income, which will be consolidated under a joint account where the dividend of the joint account is allocated to individual accounts, so that the users of the system receive higher profits. Fundamentals of the JEIA are as follows: 
(1) On behalf of a beneficiary and annual tuition fee premiums for at least one year period, starting from the beginning of the academic year is deposited by an investor in the appropriate JEIA based on the level, the year and the duration of education, and the total cost and the payment intervals (monthly, quarterly, six-monthly, annually, or as payment in full) of education.

(2) At the end of each year, depending on the circumstances, consolidated dividend income in each JEIA is allocated as beneficiary dividend. The consolidated dividend income cannot be lower than that of individual education investment account.

(3) When used as tuition fee, the dividend income will be exempted from tax.

(4) The tuition cost of the beneficiary is paid by the financing institution to the educational institution at the periods set out in the agreement between the two.

(5) The surplus of the dividend income in the joint invest account, after the tuition cost is paid, is taken into account, when the reduced-rate premium payments for the next tuition payments are deposited.

(6) In case that the student cannot complete the education (due to illness or death), the money is paid back to the investor along with the dividend income in accordance with the terms of a regular saving account. The investor is not eligible to the higher dividend income benefit accrued through joint account. The profits made by the financing institution through these practices are put to use as scholarships or loans for students.

(7) In case that the investor dies or becomes unable to pay (due to unemployment) before paying up all installments of tuition costs, an appropriate education insurance (risk/ or cumulative) becomes operational. If the money coming from education insurance program is not sufficient for the student to finish his/her education, then, in lieu of the investor, the pension insurance program of the parents, or any other public or private insurance programs the parents might have, will pay for the remaining premiums to the JEIA. Those who do not have any insurance support within family are given scholarship or student loan. The beneficiary can apply for a scholarship or a student loan at any public or private financial institution. The student will pay this financial support in forms of compulsory service, or as money after employment at the value of the year, the loan was taken with no interest, in installments or in full.

(8) The investor can deposit money in JEIA to pay for his/her own tuition cost or that of any number of students.

(9) Any students regardless of age who provide proof of enrollment in any educational institutions can benefit from JEIA.

(10) Anyone can invest in individual education investment account to pay for his/her tuition cost.

(11) Investment by those who do not have children in JEIA is considered as charitable endowment. These moneys are given to educational institutions named after the investors or to the ones where the students in need of scholarship are enrolled by the financing institutions to pay for their tuition costs.

(12) Financial institutions take precautions to keep the dividend income at the highest level in the JEIA.

(13) The JEIA can be opened in the bank or in institutions approved by the government.

(14) The JEIA is supported (through tax reduction, Social Security, Bağ-Kur, Pension Security Program payments, and etc.) and controlled by the state.

(15) Finance institution can make group buying deals or preferential trade agreement with education institutions so that the tuition costs are minimized. The profit arising from such agreements is transferred to the investor. 
(16) Financing institutions which open JEIA provide all support measures to make the investment appealing for the investor.

(17) The JEIA cannot be closed or transferred until the proof of termination of education by the given student is presented.

(18) Payments of JEIA premiums are made in money, which cannot be exchanged for any other assets. The money transferred to the education investment trust is exempt from the terms set out in topic 6 , and is not subject to penalty provisions.

(19) Those who invest in individual education investment account are directly considered as having education insurance.

(20) The tuition fee might vary by the institutions; and depending on the circumstances, the expenditure on books, stationary items, school uniforms, research material, school fees, food and accommodation, and transportation are considered as part of the tuition.

(21) Premium payment due to financial institutions can be calculated either based on the remaining amount after the payment, or based on the annual cost.

(22) Those investors who do not wish to participate in JEIA can open individual education investment account, which is a tax-exempt account with dividend income.

(23) A law on the joint and individual education investment accounts should be enacted; and the laws regulating social security, pension security, and Bag-Kur system should be necessitated by the implementation of the IESM.

(24) Individual education account is subject to the terms and conditions of individual education investment accounts except for the account properties (Çelikhan, 2007). In order for the individual and joint education investments accounts to be operational, the education system has to be adjusted to the IESM.

\section{EIP}

EIP will be a part of the education sector. The education sector, which has input and output relations with many sectors, such as teaching, construction, stationary materials, computer and software, publishing, food, clothing, furniture, and etc., is one of the major driving forces of the economy. It creates sustainable employment and generates added value in a wide range of production areas and processes. EIP will be established as high-profit generating finance institutions within the capital market on the basis that the participants invest in large-scale education projects in order to pay their specified education cost. EIP builds and operates educational facilities at all levels of education, dormitories for students, training courses (language, vocational, sport, music, art, and etc.), and undertakes through production or procurements the materials and services needed by the aforementioned facilities.

(1) These are some considerations regarding EIP. A law regarding EIP must be enacted.

(2) Any household who has or plans to have children will be entitled to buy stock shares of specified amount, installments, and payment rate, depending on the level of education desired, the year of schooling, costs involved, and income level of the household.

(3) Stock dividends of shares will be exempt from income tax.

(4) At each disbursement time, the amount of the profit made from the stock dividends will be deducted from the remaining payments, and will be added to the partnership share so that the profit margin will increase and the payment time will be shortened. When the student starts to go to school, the cost of education will be 
deducted from the partnership share in the interest of the beneficiary according to the specified payment period agreed by the educational institution.

(5) It is for the benefit of low income families to start buying equity shares at least one year ahead of the start of the schooling for their children to make their payments easier.

(6) In EIP, it is essential that the investor not only gains benefit from his/her own investment, but also takes shares from the higher profit gained by the total capital accumulated through partnership. Through this stipulation, any increase in the number of partners in the program means a decrease of education cost per capita.

(7) In case that the partners of the EIP declare bankruptcy or that profit from the investment is less than the annual minimum earned interest, the state will interfere as a guarantor.

(8) The education expenses of the beneficiary will be paid against invoice to the relevant education institution by the EIP in accordance with predetermined periods and the amounts.

(9) It is important that the profit made through in advance or bulk purchases will be distributed among partnership shares.

(10) Once the profit which falls to the beneficiary's share reaches the amount of predetermined cost of education, payments in installments will come to an end. However, the profit made by the EIP from its collective account will be used to balance off investments in bursaries, credits, and retirement funds.

(11) EIP expires at the end of schooling of the beneficiary.

(12) If profit from EIP is used outside of investment in education or educational expenses, it will be subjected to the income tax and a penalty of $10 \%$.

(13) Partners in EIP can take advantage of group discounts when enrolling in enterprise-established or contracted schools.

(14) EIP guarantees the payment of education cost as specified in the contract to the relevant institutions. All necessary corporate affairs to this effect will be undertaken by EIP.

(15) An EIP will not be an impediment to the schooling of the beneficiary at an institution that is not affiliated with the partnership.

(16) Those who would like to make donation for education will buy a share from EIP for each student he/she would like to make the donation for. The EIP will distribute the donation to the specified student or the ones that are selected based on merit or financial need.

(17) In case of a death/disability/retirement of a partner who has signed the EIP contract, the amount of dividend is not enough to cover education cost, then the beneficiary is entitled to a suitable education insurance scheme. In the case that the fund from the education insurance scheme is not enough to cover the cost of education, then the terms laid down in the contract will be carried out by the retirement insurance agency of the investor. In case that the student is not eligible to any insurance, he/she will be granted credit or bursary. The beneficiary will pay back the credit during or after graduation at the credit value of that year in terms of compulsory service or money free of interest.

(18) The state will take necessary legal actions to amend internal or inter-organizational systems in order to make sure that retirement insurance agencies will be able to take on the terms and conditions of the partnership contract on behalf of the investor as prescribed by the model.

(19) The retirement insurance agency, which takes the partnership on behalf of the investor, will not terminate the partnership, unless its expenditure for each beneficiary is reimbursed as dividend. There will be 
legal regulations to this end.

(20) In case of death or disability/unemployment of the partner, if the beneficiary is still in school, the dividend will be spend to cover the remaining education cost of the student; or the stipulations in topic 17 are in effect. If the beneficiary is no longer in school, the remaining money will be paid back to the beneficiary or the investor/successors as dividend off and liable to tax.

(21) EIP is subject to state inspection and support (tax exemption, retirement insurance investment, and land provision).

(22) Those who invest in EIP will be entitled to benefits from an appropriate education insurance scheme.

\section{Conclusions}

When education programs and levels are taken into account the Financial Management Models of IESM, households not only will benefit in terms of education cost, but also will enjoy opportunities of employment and higher education quality provided by the IESM system. If investing in JEIA and EIP becomes appealing to households even before they have children or just after they have children, the money accrued in these accounts will help reduce Turkey's demand for foreign credits and increase investment credits

In a simple, calculation can be illustrated that the benefits of payments of education cost through financing institutions as proposed by the model are rather individual payments by households. When the IES model becomes operational, the profits made through bulk deposits and preferential trade will be given back to the stakeholders, thus will spread to the society as a whole. If implemented with duly precautions and security measures, Turkey can set an example for other countries with IESM.

\section{References}

Akbank sigorta verileri. (2007). Akemeklilik for education insurance. Retrieved from www.akemeklilik.com.tr/hayat_urunleri/surekli_egitim_sigortasi.asp

Axa Oyak sigorta verileri. (2007). Axa Oyak for education insurance. Retrieved from www.axaoyak.com.tr/u-ce.asp

Çelikhan, S. (2007). Katılımlı, Ödenebilir, Yararlı, Etkin, Sigortalı Eğitim Sistemi (Köye-SES) Modeli (The model of participating payable, profitable, potent insured education system (4pes-IESM)). Kocaeli: Gebze Yüksek Teknoloji Enstitüsü.

Devlet Planlama Teşkilatı. (2007). Beş Yıllık Kalkınma Raporu (Five-year development report). Retrieved from http://www. dpt.gov.tr

Fortis Bank A.Ş. sigorta verileri. (2007). Fortis for education insurance. Retrieved from www.fortis.com. tr/bireysel/ideal_egitim_sigortasi.jsp

IRS. (2007). IRS for insurance. Retrieved from http://www.irs.gov/newsroom/article/0,,id=107670,00.html

TEB sigorta verileri. (2007). Tebsigorta for education insurance. Retrieved from www.tebsigorta.com. tr/BireyselSigortacilik/CocukEgitimiOzellikler.aspx

Türkiye İstatistik Kurumu. (2007). Data of Turkish Statistical Institute (TSI). Retrieved from http://www.tuik.gov.tr

Vakıf Bank sigorta verileri. (2007). VakifBank for insurance. Retrieved from www.vakifbank.com.tr/1501.aspx 